\title{
Determinants of Success among Clients of a Trade and Industry Government Agency: A Basis for a Capability Building Program
}

\author{
Jason B. Montecañas
}

\author{
Capitol University, Philippines
}

\begin{abstract}
Entrepreneurship has always been considered a prime mover in nation building and societal progress. Entrepreneurs play a pivotal role in promoting economic activities through the creation of jobs, in growing local industries and in enabling business innovation. This study looked into the determinants of success of businesses who availed of the advisory services of a Trade and Industry government agency. The results of the study became the basis for developing a comprehensive enterprise development track as capability building program. Participants in this study are business owners and government personnel who provide broad but complementary responses. The findings were that the socio-economic profile has relative to no bearing to the success of the business. When looking at their entrepreneurial skills, creative thinking was discovered to have the most positive impact, while marketing and selling were marked low level skills. The Negosyo Center also needs to improve its communication channels to ensure participants become more aware of all its offerings. The study discovered that those who participated in the center's programs experienced an overall increase in income, production and number of employees. A capability building program is needed to strengthen and sustain the performance of the micro and small enterprise.
\end{abstract}

Keywords: Entrepreneurship, Go Negosyo, Micro and Small Enterprises, Trade and Industry, Philippines

\section{Introduction}

The current financial difficulties confronting numerous nations over the globe has prompted States in vigorously advancing entrepreneurial activity. The importance of business enterprise to a country's economic development has been featured in numerous researchers (e.g. Davidsson et al, 2006) and presently, it is perceived that education and training opportunities assume a key job in developing future business visionaries and in building the capacities of existing businesses, especially the people (Henry et al, 2003).

Entrepreneurship has an important role in the creation and growth of businesses and therefore the growth and success of countries (Hisrich et al. 2013). Entrepreneurship is the symbol of business achievement and persistence (Kuratko and Welsch 2004). Practically all clarifications for business, and for free enterprise itself, depend on enterprise as a foundation. A lot of individuals around the globe participate in pioneering movement (Shane, 2003).

Entrepreneurship takes various structures and it shows up in both little and big organizations, in new and set up organizations, in the formal and casual economies, in lawful and unlawful exercises, in inventive and traditional cases and in all locales and monetary divisions (Westhead et al. 2011). Entrepreneurship is considered the key driver to economic development. Governments and academics encourage entrepreneurship due to its importance to employment creation and gross domestic product (GDP) (Ahmad, 2010). Without the never ending creation of new businesses, our economy would stop (Zimmerer and Scarborough 1996).

Entrepreneurship is not just confined to any one particular industry, country or group of persons; it exists in everywhere depending on an individual's desire. Enterprising behavior has been found in all social orders, and 
in a wide range of financial conditions. While the term more often than not alludes just to an individual, it is additionally conceivable to discover entire associations that can be delegated pioneering in the manner in which they work together and look to develop (Schaper, 2004).

The entrepreneur is one who drives the process of economic growth and mediates the inputs and outputs of the economic system (Vosle, 1994). In the broadest sense, an entrepreneur may be described as a person who has the ability to explore the environment, identify opportunities for improvement, mobilize resources and implement actions to capitalize on those opportunities. Entrepreneurs have a well-defined sense of opportunities. After identifying the opportunities, they then creatively assemble the necessary resources to capitalize on them (Zimmer and Scarborough, 2005; Thomas and Mueller, 2000). As risk takers, entrepreneurs bring about new products and services, and indeed, add colors to a society (Zimmer and Scarborough, 2005).

Globally, different governments over the world are steadily perceiving the positive effect that the formation of new organizations can have on work levels, alongside the focused increases that little firms can convey to the commercial center (Scase, 2000). Additionally, despite the fact that business enterprise gives aids with terms of social and economic advancement, it comparably offers benefits as far as individual satisfaction, with business enterprise presently getting through the hindrances of class, age, sex, sexual introduction, and race.

In the Philippines, a Micro, Small and Medium Enterprise (MSME) is defined as any business activity whose asset size, excluding land, is not more than P 100 million and whose number of employees does not exceed 200, regardless of type of ownership and nature of business (Magna Carta for MSMEs or RA 9501, 2008). In 2016, the number of MSMEs accounted for $99.6 \%$ of the total number of industries in the Philippines. Not only do MSMEs comprise the majority of national economic activities, but they also contribute most to employment generation, accounting for $61.2 \%$ of the total jobs generated and $35.7 \%$ of total value added (MSME Development Plan 2011-2016). All these data prove the crucial role of MSMEs in the economic vitality of the country. It is for this reason that the Philippine government saw the need to further strengthen the MSME sector as their success can very well spell the future of the economy (Philippine Statistics Authority (PSA), 2016).

MSMEs are regarded as the lifeblood of the economy, playing a crucial role in the value chain. They are not only the backward and forward linkages of large industries, they also spawn economic activity of their own, creating niches in the market and diversifying business. Their indispensable existence is undeniable to every economy.

However, despite accounting for most of the industries and generating most of the employment, MSMEs have relatively low value added to the economy as compared to other Southeast Asian countries. This is a serious indication that the growth of MSMEs in the Philippines is stunted and should be a wake-up call for the government and business enabling organizations to re-assess the appropriateness of their interventions. This fueled the conduct of this study, to find out the determinants of MSE success factor and come up with an effective capability building program to help the MSEs succeed in business (Senate Economic Planning Office (SEPO) Publications, 2012).

This study seeks to ascertain what profiles and entrepreneurial skills of micro and small enterprises help determine their success. It shall also identify what interventions are appropriate for their development. This study is anchored on the Innovation theory (Schumpeter, 1934, 1982) as cited by (Hanush, H. and Pyka, A., 2007). As indicated by Schumpeter, economic advancement is not a programmed procedure; it must be intentionally and effectively advanced by some organization inside the framework. He called the operator who starts the above changes as a business person. He included that the operator who gives financial authority that changes the underlying state of the economy and causes irregular powerful changes is a business person. As indicated by Schumpeter a business person is a 'trailblazer' and his 'advancement' is an innovative reaction to a circumstance. 
The Managerial Skills and Leadership Theory (Hoselitz, B.F. 1952) as referred to by (Md. Shafiul Alam, Golam Mohiuddin, 2014) is additionally essential when contemplating MSEs. Hoselitz (1952) says, that notwithstanding being persuaded by the desires for benefit, a business person should likewise have some administrative abilities. All the more significantly he should be able to lead. He keeps up that money related abilities have just an auxiliary thought in business enterprise and remarks that administrative aptitudes and initiative are the most critical components of business.

The achievement motivation theory of McClelland (1961) also describes the innovative characteristics of entrepreneurial role. McClelland (2006, 2009) identified two characteristics of entrepreneurship. First is doing things in a new and better way. This is synonymous with the innovative characteristics given by Schumpeter (1934). Second is decision making under uncertainly, i.e. risk as identified by Cantillon (1755). McClelland's major contribution lies in extending our understanding of casual sequence of entrepreneurial behavior. McClelland has explained the entrepreneur's interest in profitability in terms of a need for achievement. For people with high need for achievement, profit is a measure of success and competence.

Since McClelland presented his theory in 1961, much of the discussion in entrepreneurship has been concentrated on the individual. The individual plays a very important role in entrepreneurship (Carland Jr. and Carland, 1997). When an entrepreneur begins a business, they bring a set of human capital to the business (Dollinger 1995). Thusly, the business turns into an extension of the business person as a person.

Zhang and Bruning (2011) and Littunen (2000) claims that since starting up a new business is an individual decision, the individual's characteristics as an entrepreneur are essential when studying entrepreneurship. However, studying an individual can be extremely complex (Littunen 2000). Particularly if an entrepreneur is dependent on external funding sources, they may place limits on the entrepreneur's personality, as it is expressed via the business venture (Carland Jr. and Carland 1997). Additionally, clients will restrain the opportunity of the business visionary to regard the business as an extension of identity. By the by, because of the extent of this examination paper, the main issue will be the effect of pioneering identity on a business adventure.

Researches focused on the individual approach of the entrepreneurship mostly keep their focus on psychological, demographic and personal traits. This methodology expresses that business people have explicit qualities, demeanors and requirements. This would imply that brain research, individual attributes and an individual's encounters decide business enterprise. As per the individual approach, individuals with specific attributes, for example, inner locus of control and should be autonomous are bound to end up business visionaries later on. (Bulut, et al., 2010).

However, a more holistic approach in analyzing the determinants to business success can be borrowed from the conceptual framework of Reeg, which categorizes the factors into four school of thoughts namely: (1) Business environment, (2) Personal and professional networks, (3) Enterprise characteristics, and (4) Entrepreneur characteristics.

In Reeg's Onion Model, these four schools of thought are a layered representation of the overall personality of the business as first influenced by the personal characteristics of the entrepreneur, second by the unique characteristics of the business, third, through its personal and professional networks and finally, by its environment. At the core of the onion model is the entrepreneurship characteristics. These includes: age, education and work experiences, motivation and risk-taking ability. The second level tackles enterprise characteristics such as age of enterprise, location, sector, gender, formality, access to finance and absorptive capacity. The third and fourth levels include analysis of the following: (1) personal and professional networks; and (2) business environment, respectively.

To improve on the findings of Hampel-Milagrosa, the study will also borrow some of the literature sources written by different authors in the field to help provide a deeper insight into the micro and small enterprises 
success factors. These are: Lussier (1995); Praag (2003); Shonesy and Gulbro 2004); Walker and Brown (2004); Lussier and Halabi (2010). Success of enterprise is evidenced by increase in income, increase in productivity and increase in number of employees (Hampel-Milagrosa, 2014). This will eventually result in the creation of an effective capability building program.

The development of MSEs is undoubtedly important for a country's economy. However, not everyone is guaranteed to succeed in business since there are innate and acquired qualities necessary for success. It is also assumed in this paper that although entrepreneurial qualities can be learned, a considerable incubation period of more than a year is necessary for a change of mindset, acquiring of values and skills. Since the paper covers only a period of one year, it assumes that MSEs who remained and succeeded already possessed a certain level of those qualities necessary for success in business.

The Philippines has a record of 780,437 business establishments according to the 2009 List of Establishments of the National Statistics Office (NSO). 91.40\% of the total number of establishments are micro enterprises, $8.2 \%$ are small enterprises and $0.4 \%$ constitutes the medium enterprises. 50\% are engaged in wholesale and retail, $14 \%$ are in manufacturing, while the remaining 12\% are hotels and restaurants. (Almeda, Baysic-Pobre, 2013). The 2010 number of Establishments by firm size of the National Statistics Office (NSO) recorded a total of 777,687 business enterprises operating in the Philippines. Micro, small and medium enterprises (MSMEs) account for $99.61 \%(774,664)$ of the total establishments, of which $91.3 \%(709,899)$ were microenterprises, $8 \%$ $(61,979)$ were small enterprises, and $0.3 \%(2,786)$ were medium enterprises. Large enterprises made up the remaining $0.4 \%(3,958)$.

The most significant contribution attributed to MSMEs is on job creation. In 2009, MSMEs contributes 63\% to Philippine employment. Almeda and Baysic-Pobre in their review of related literature cited some studies that points to MSMEs as the major contributor to job creation. (Almeda, Baysic-Pobre, 2013). Samar identified the significant role of MSMEs in many areas aside from employment generation and cited the following: (1) MSME promotes rural industrialization and decentralization of industries, (2) MSME foster economic activities by stimulating entrepreneurial spirit; and (3) MSMEs provides backward and forward linkages to existing industries necessary to its sustainability.

A study of micro, small and medium enterprise of East Asian counties revealed its significance to the economy. It contributes most to employment generation and it is a crucial player in the supply chain being the forward and backward linkage to big industries (Harvie, Lee 2002).The role of MSME to the economic growth is henceforth undeniable. The Philippine government recognizes this urgency for MSME development as evidenced by the numerous laws for the advancement of MSMEs, such as Magna Carta for SMEs as amended by RA 8289, Barangay Micro Business Enterprise Act of 2002 and the Go Negosyo Act of 2014. This is not to mention the regularly updated short term development plan for MSMEs of which the most recent that was adopted is MSME Development Plan for 2011-2016. No matter the effort of the Philippine government, there is something lacking. In the research conducted by Almeda and Baysic-Pobre, it was noted that the number of MSMEs in the Philippines did not accrue positive increase from 1999 to 2010. In fact, the number of medium enterprises declined by $1.3 \%$ (2013). Philippine MSME also contributed least value added to the economy compared to other Southeast Asian countries.

The intent of the study is to find out the determinants of success of micro and small enterprises which have availed of the services of Trade and Industry Center from January to December 2017. Specifically, it will seek to answer the following questions: First, what is the profile of the respondents in terms of sex, marital status, educational background, business knowledge, sources of capital, and years of operation and nature of business? Second, what is the respondents' level of entrepreneurial skills in terms of creative thinking, planning and research, organization and decision making, marketing and selling; and business management? Third, what are the entrepreneurial challenges and interventions presented to the respondents in terms of business needs, knowledge of services, and availment of services? Fourth, what is the success rate of MSEs after they availed 
the services of the Negosyo Center in terms of increase in number of employees, increase in income, and increase in production? Fifth, is there a significant difference between the respondents' profile, and their entrepreneurial skills in terms of creative thinking, planning and research, organization and decision making, marketing and selling; and business management? Sixth, is there a significant difference between the respondents' profile, and challenges and interventions in terms of business needs, knowledge of services, and availment of services? Seventh, is there a significant relationship between entrepreneurial skills, and challenges and intervention in terms of business needs, knowledge of services, and availment of services? Eighth, is there a significant relationship between entrepreneurial skills, and success rate in business in terms of increase in number of employees, income, and production? Finally, what capability building program can be developed to improve the success rate of business among MSEs?

\section{Methods}

In this study, descriptive research was used with a mixed method of study using quantitative and qualitative approaches. The quantitative aspect of the research seeks to determine the success rates of MSEs availing assistance from a Trade and Industry Center. It also ascertains the correlations between entrepreneurial characteristics as causative factors for business success, thru statistical techniques. Using the simple method of purposive sampling, a total of ninety-three (93) respondents of the total population is drawn. Purposive sampling, also known as judgmental, selective or subjective sampling, was a type of non-probability sampling technique. Non-probability sampling focuses on sampling techniques where the units that are investigated were based on the judgement of the researcher. All of the respondents are micro and small enterprises that graduated from the Enhanced Business Learning Session and Kapatid Mentor Me Program facilitated by the Negosyo Center.

A survey was conducted using a closed ended questionnaire (questionnaire that provides a number of alternatives answers from which the respondent was instructed to choose) was used to collect primary data. The interview guides were structured in such a way that opinions answers be recorded while some questions were structured along the Likert scale rating. Survey questionnaires were given to ninety-three (93) respondents. The research instrument was created by the author and were subjected to a face validity test by presenting it to experts. The said questionnaire consists of five major parts. Part one was intended for the Profile of the MSE owners. The second part of the questionnaire focused on the entrepreneurial skills of the MSE owners specifically on the following: Creative Thinking, Planning and Research, Organization and Decision Making, Marketing and Selling, and Business Management. The third part of the questionnaire focused on the success in indicators of enterprises specifically on the following increase in number of employees, increase in income, and increase in productivity. The fourth part focused on the Negosyo Center Services. And the fifth part of the questionnaire focused on the additional services that the Negosyo Center may offer. Information was also gathered through secondary sources from the Negosyo Center records, census data, reports, research papers and other review of literature. The survey results were tallied into a multi-variate table and used a T-Test and ANOVA, the test has determined if there is significance or dependency of qualities of MSEs with their successes.

Primary method of data collection was employed through interviews and surveys. Key informant interviews (KII) were conducted with the aid of a structured questionnaire. True to the quantitative approach of the study, a survey was also conducted to generalize the profiles and to ascertain the percentage of successful MSMEs assisted by the Negosyo Center. According to the records of the Trade and Industry Center, there were 100 registered and legitimate MSEs who graduated from the Enhanced Business Learning Session and Kapatid Mentor Me Program between January to December 2017.

A pilot study was also administered to thirty 2015-2016 graduates of the Negosyo Center. The pilot study procedures were the same as the procedures for the administration of the actual survey (i.e., completed informed 
consent required before the respondents could do the pilot study). Cronbach's alpha coefficient was calculated to assess the reliability of the scores produced by the survey instrument. Huck (2000) writes, a third method for assessing internal consistency was referred to as coefficient alpha, as Cronbach's alpha, or simply as alpha. The average reliability test of the entrepreneurial skills is 0.92 .

\section{Results and Analysis}

In Problem 1, the data showed respondents' sex was dispersed almost evenly with females slightly higher than males (51.6\% vs $48.4 \%$ ). Majority or $74 \%$ of the respondents are married or have been married. Only about $26 \%$ of the respondents were single. In the educational background, $75 \%$ of the respondents have a college degree or have obtained higher education. Business acumen or knowledge about the business is mostly earned through trainings at $37.6 \%$, and experience at $30.1 \%$. Only about $3.2 \%$ of the participants learned their how to run their business through self-taught, while $12.9 \%$ of the respondents gained experience from running their own family business. $68.9 \%$ of respondents sourced their funds from an income stream that included savings from salaries at $28.0 \%$, saving from other business undertakings at $9.7 \%$ and savings from other sources with $31.2 \%$. Majority of the owners are also relatively new at $55.9 \%$ compared to only $1.1 \%$ who can be considered well-established. The natures of the business of the respondents are varied with a majority of them in the manufacturing industry at $33.3 \%$ specifically under the food processing sector, shortly followed by service industry at $27 \%$ and in third was Trading/ Buy and Sell at 25\%. The remaining respondents (10.8\%) come from the agricultural sector.

In several studies, it was discovered that women are more dominant and likely to undertake entrepreneurial activity in countries where the state sector is larger, but the rule of law is not generally found to have genderspecific effects (Estrin \& Mickiewicz, 2011). In the domestic setting, the Philippines has been awarded by MasterCard Index of Women Entrepreneurs as the 9th in the globe as having positive economic conditions that are conducive for women entrepreneurs. New Zealand was top on the list. The study evaluated 57 economies representing 78\% of the entire world's labor work force. The Kaufmann Foundation Study (2017) revealed that while there are advantages to being a single entrepreneur, when you are in a healthy personal relationship, like marriage, you are more likely to succeed in business. In the study, the conjugal aspect of marriage helps develop skills and techniques in communication, and learning habits like diligence, respect and reliability. According to another research cited in the Journal of Human Resources, married men do earn more in business and are able to make smarter decisions. One of the best points of interest that wedded business people have over their single partners is a work-life balance since it's something that they manage each day (McGowan et. al., 2012).

In Problem 2 of this research, the data revealed Creative Thinking as an important entrepreneurial skill at 3.37, compared to the rest. The indicators under this level include "I find ways to solve problems, I look at something in a new way, and I devise new ways to carry out tasks". The lowest item is Marketing and Selling at 3.20, with the indicator on, "I know how to sell ideas and products and can describe what selling involves as the primary factor. This means that the respondents need to improve their ideas on selling the products, which lead to a greater revenue (Netessine, Savin, \& Xiao, 2004). Overall, the respondents assessed themselves as "Very Good" in their level of entrepreneurial skills.

In McLarty and Dousios (2006), the term skill embraces the ideas of competence, proficiency, attributes, and the ability to do something well and is related closely to knowledge, expertise, and capability. Markman and Baron (2003) pointed out that the chances of entrepreneurial success growing in the presence of personal characteristics and skills such as self-efficacy, ability to recognize opportunities, personal perseverance, human and social capital and prevalent social abilities are expanded. Albeit a portion of these attributes might be treated as close to home qualities, Markman and Baron confirmed that the majority of the qualities and aptitudes can be learned by methods for suitable short-term training. 
In Problem 3 of this research, the data suggest that they identified exposure and trade fairs as the greatest need that should be addressed in terms of business success, although they also ranked all as a needed to a great extent. All the indicators mentioned in the table were services offered by the Trade and Industry - Negosyo Center. Yusuf (1995) summarized four major critical factors for entrepreneurial success: good management, access to financing, personal qualities and satisfactory government support. This is also supported by Jasra et. al, (2011) where it said that financial resources are the most critical factor for the success of the business, and marketing strategies, technological resources, government support and entrepreneurial skills are regarded as contributory factors. In the data for entrepreneurial challenges and interventions in terms of knowledge of services, results show that the highest item is "Packaging and Labeling" with a mean of 3.44 or "Know to a great extent". The lowest items are "Technology study mission / technology transfer and Product and design development for food", both with a mean of 3.33. The respondents were also mostly aware of the services the Negosyo Center as all items resulted to "Know to a great extent". This result is important because it gauges the awareness, depth, extent of awareness and relevance of the various programs of the center vis-à-vis the unique challenges the MSEs experience in their businesses. In the level of awareness of the respondents on the services provided by the Negosyo Center prior to their engagement, the results show respondents believe trainings and seminars as the most availed business advisory service of the center. This indicator ranked first at 3.56 or availed to a great extent.

This is followed closely by Packaging and Labeling, and Coaching Session with a mean of 3.54. Business consultancies / Information and Data Referral came third with a mean of 3.47. While Product and Design Development ranked lowest with a mean of 3.25 or availed in some extent. While the ranking of these indicators are important, the overall mean is at 3.42 or availed to a great extent. The implications are that the current program of the Negosyo Center is in tune to the needs of the MSEs. This is important because the matching of the programs to what is currently needed by the businesses at the grassroots, will determine effectiveness of the entire Negosyo Center. This alignment shows the Negosyo Centers strong adherence to its avowed mission and vision. The Negosyo Center should continue providing relevant training and seminars, while encouraging more participants to join the program on product design and development for food.

In Problem 4 where the success rate of the MSEs in terms of increase in number of employees, income and production, were gauged after they availed of the services of the Negosyo Center, the data showed that in terms of increase in number of employees before availment of the service of the Negosyo Center, $62 \%$ of the respondents reported a low increase in manpower by adding only 1 to 2 staff. $22 \%$ reported a moderate increase in manpower with an additional 3-4 staff added to their organization. 1\% reported an increase of 6 staff and 14\% reported a zero increase. This data on the growth of the business in terms of additional employees is important because this variable is a clear indicator of entrepreneurial progression. When looking at the data on increase in income, 36 out of 93 respondents reported a high increase (up to $75 \%$ positive change) in their revenue compared to how their business performed before availing of the services of the Negosyo Center. This is compared to 25 respondents who reported a very high increase in their income, spiking up to $100 \%$ compared to their previous performance. The remaining 32 respondents reported a moderate $26 \%-50 \%$ income increase. This report on income increases are crucial because when compared to the data on any increases in production, the study revealed that $40 \%$ of the respondents experienced high increases in their production levels with $30 \%$ at both very high and moderate levels. Simultaneous increases in staffing, production and income are good indicators of business performance, and because these all happened after the respondents availed of the services of the Negosyo Center, it is possible to align causality of these success metrics to the overall performance of the center.

In Problem 5, results showed all of the socio demographic variables have a significant impact to the entrepreneurial skills of the respondents. Any rise of these variables can mean an influence in the results of how successful the business can become. Once entrepreneurial potential is identified, resources can be channeled and more effectively used to promote entrepreneurship and enhance its skills (Chen, Greene, \& Crick, 2014). 
Table 1. Test of Difference of the Respondent's Profile and Entrepreneurial Skills

\begin{tabular}{|c|c|c|c|c|c|c|c|}
\hline INDICATORS & Variation & Df & $\begin{array}{l}\text { Sum of } \\
\text { Squares }\end{array}$ & $\begin{array}{l}\text { Mean } \\
\text { Square }\end{array}$ & F-Stat & P-Value & Decision \\
\hline \multirow{3}{*}{ Sex } & Between & 1 & 0.1718 & 0.1718 & 19.45644 & 0.000138 & Accepted \\
\hline & Within & 28 & 0.2472 & 0.0088 & & & \\
\hline & Total: & 29 & 0.4190 & & & & \\
\hline \multirow{3}{*}{ Marital Status } & Between & 3 & 0.9007 & 0.3002 & 18.43939 & 0.00001 & Accepted \\
\hline & Within & 56 & 0.9118 & 0.0163 & & & \\
\hline & Total: & 59 & 1.8125 & & & & \\
\hline \multirow{3}{*}{$\begin{array}{l}\text { Educational } \\
\text { Background }\end{array}$} & Between & 2 & 0.4841 & 0.2420 & 14.75912 & 0.000014 & Accepted \\
\hline & Within & 42 & 0.6888 & 0.0164 & & & \\
\hline & Total: & 44 & 1.1728 & & & & \\
\hline \multirow{3}{*}{$\begin{array}{l}\text { Business } \\
\text { Knowledge }\end{array}$} & Between & 3 & 1.6175 & 0.5392 & 11.65318 & 0.00001 & Accepted \\
\hline & Within & 56 & 2.5909 & 0.0463 & & & \\
\hline & Total: & 59 & 4.2084 & & & & \\
\hline \multirow{3}{*}{$\begin{array}{l}\text { Sources of } \\
\text { Capital }\end{array}$} & Between & 4 & 2.0555 & 0.5139 & 27.43195 & 0.00001 & Accepted \\
\hline & Within & 70 & 1.3113 & 0.0187 & & & \\
\hline & Total: & 74 & 3.3669 & & & & \\
\hline \multirow{3}{*}{$\begin{array}{l}\text { Years in } \\
\text { Operation }\end{array}$} & Between & 3 & 1.0576 & 0.3525 & 4.15422 & 0.009974 & Accepted \\
\hline & Within & 56 & 4.752 & 0.0849 & & & \\
\hline & Total: & 59 & 5.8096 & & & & \\
\hline \multirow{3}{*}{$\begin{array}{l}\text { Nature of } \\
\text { Business }\end{array}$} & Between & 3 & 2.4371 & 0.8124 & 96.16945 & 0.00001 & Accepted \\
\hline & Within & 56 & 0.4731 & 0.0084 & & & \\
\hline & Total: & 59 & 2.9102 & & & & \\
\hline
\end{tabular}

In Problem 6, on the One Way Analysis of Variance on the Entrepreneurial Challenges and Interventions presented to the Respondents in terms of Business Needs when respondents are grouped according to Sex, Marital Status, Educational Background, Business Knowledge, Sources of Capital, Years in Operation and Nature of Business. The data exposed that Marital Status (P-value=0.001931), Educational Background (Pvalue $=0.031338)$, Business Knowledge $(\mathrm{P}$-value $=0.00001)$, Years in Operation $(\mathrm{P}$-value $=0.00001)$ and Nature of Business (P-value $=0.00001$ ) are below the significant level of 0.05 . This means that they have significance difference in Entrepreneurial Challenges and Interventions in terms of Business Needs. 
Table 2. Test of Difference of the Respondents' Profile, and Challenges and Interventions in terms of Business Needs

\begin{tabular}{|c|c|c|c|c|c|c|c|}
\hline INDICATORS & Variation & Df & $\begin{array}{l}\text { Sum of } \\
\text { Squares }\end{array}$ & $\begin{array}{l}\text { Mean } \\
\text { Square }\end{array}$ & F-Stat & P-Value & Decision \\
\hline \multirow{3}{*}{ Sex } & Between & 1 & 0.0135 & 0.0135 & 3.99082 & 0.061091 & $\begin{array}{l}\text { Not } \\
\text { Accepted }\end{array}$ \\
\hline & Within & 18 & 0.0610 & 0.0034 & & & \\
\hline & Total: & 19 & 0.0745 & & & & \\
\hline \multirow{3}{*}{ Marital Status } & Between & 3 & 0.1233 & 0.0411 & 6.03967 & 0.001931 & Accepted \\
\hline & Within & 36 & 0.2450 & 0.0068 & & & \\
\hline & Total: & 39 & 0.3683 & & & & \\
\hline \multirow{3}{*}{$\begin{array}{l}\text { Educational } \\
\text { Background }\end{array}$} & Between & 2 & 0.0673 & 0.0337 & 3.94759 & 0.031338 & Accepted \\
\hline & Within & 27 & 0.2303 & 0.0085 & & & \\
\hline & Total: & 29 & 0.2976 & & & & \\
\hline \multirow{3}{*}{$\begin{array}{l}\text { Business } \\
\text { Knowledge }\end{array}$} & Between & 3 & 0.6424 & 0.2141 & 12.73212 & 0.00001 & Accepted \\
\hline & Within & 36 & 0.6054 & 0.0168 & & & \\
\hline & Total: & 39 & 1.2478 & & & & \\
\hline \multirow{3}{*}{$\begin{array}{l}\text { Sources of } \\
\text { Capital }\end{array}$} & Between & 4 & 0.1438 & 0.036 & 2.32085 & 0.071257 & $\begin{array}{l}\text { Not } \\
\text { Accepted }\end{array}$ \\
\hline & Within & 45 & 0.6971 & 0.0155 & & & \\
\hline & Total: & 49 & 0.8409 & & & & \\
\hline \multirow{3}{*}{$\begin{array}{l}\text { Years in } \\
\text { Operation }\end{array}$} & Between & 3 & 1.0409 & 0.3470 & 38.82265 & 0.00001 & Accepted \\
\hline & Within & 36 & 0.3217 & 0.0089 & & & \\
\hline & Total: & 39 & 1.3626 & & & & \\
\hline \multirow{3}{*}{$\begin{array}{l}\text { Nature of } \\
\text { Business }\end{array}$} & Between & 3 & 0.1110 & 0.0370 & 10.54597 & 0.00004 & Accepted \\
\hline & Within & 36 & 0.1263 & 0.0035 & & & \\
\hline & Total: & 39 & 0.2373 & & & & \\
\hline
\end{tabular}

Entrepreneurial Challenges and Interventions can provide motivation and skills to improve entrepreneurial behavior, the availability of resources has a moderating effect on both entrepreneurial behavior and achievement. In addition to explaining entrepreneurship in general (Sriram, Mersha, \& Herron, 2007). Moreover, the sharp difference in genetic influences on entrepreneurship across gender groups and highlight the different challenges that men and women face in their entrepreneurial endeavors, especially in entrepreneurial interventions (Zhang et al., 2009).

Furthermore, the Sources of Capital (P-value=0.071257) and Sex (P-value=0.061091 has no significant difference since the $\mathrm{p}$-value are above 0.05 level of significance. This implied that they are homogenous on their source of capital which identifies the entrepreneurial recycling - whereby successful cashed out entrepreneurs reinvest their time, money and expertise in supporting new entrepreneurial activity; and an information-rich environment in which this information is both accessible and shared. A key player in this context is the dealmaker who is involved in a fiduciary capacity in several entrepreneurial ventures and interventions (Mason, Colin; Brown, 2013).

Table 3 below demonstrates the One Way Analysis of Variance on the Entrepreneurial Challenges and Interventions presented to the Respondents in terms of Knowledge of services when respondents are grouped according to Sex, Marital Status, Educational Background, Business Knowledge, Sources of Capital, Years in 
Operation and Nature of Business. The data shown that Sex (P-value=0.00004), Marital Status (Pvalue=0.029949), Educational Background ( $\mathrm{P}$-value=0.000014), Business Knowledge (P-value=0.00001), Sources of Capital $(\mathrm{P}$-value=0.00001), Years in Operation $(\mathrm{P}$-value $=0.00001)$ and Nature of Business $(\mathrm{P}$ value $=0.00001)$ are below the significant level of 0.05 . This means that they have significant difference in Entrepreneurial Challenges and Interventions in terms of Knowledge of services.

Table 3. Test of Difference of the Respondents' Profile, and Challenges and Interventions in terms of Knowledge of Services

\begin{tabular}{|c|c|c|c|c|c|c|c|}
\hline INDICATORS & Variation & Df & $\begin{array}{l}\text { Sum of } \\
\text { Squares }\end{array}$ & $\begin{array}{l}\text { Mean } \\
\text { Square }\end{array}$ & F-Stat & P-Value & Decision \\
\hline \multirow{3}{*}{ Sex } & Between & 1 & 0.0980 & 0.0980 & 29.02271 & 0.00004 & Accepted \\
\hline & Within & 18 & 0.0608 & 0.0034 & & & \\
\hline & Total: & 19 & 0.1588 & & & & \\
\hline \multirow{3}{*}{ Marital Status } & Between & 3 & 0.1243 & 0.0414 & 3.33667 & 0.029949 & Accepted \\
\hline & Within & 36 & 0.4470 & 0.0124 & & & \\
\hline & Total: & 39 & 0.5712 & & & & \\
\hline \multirow{3}{*}{$\begin{array}{l}\text { Educational } \\
\text { Background }\end{array}$} & Between & 2 & 0.0513 & 0.0256 & 1.81987 & 0.181368 & $\begin{array}{l}\text { Not } \\
\text { Accepted }\end{array}$ \\
\hline & Within & 27 & 0.3804 & 0.0141 & & & \\
\hline & Total: & 29 & 0.4317 & & & & \\
\hline \multirow{3}{*}{$\begin{array}{l}\text { Business } \\
\text { Knowledge }\end{array}$} & Between & 3 & 1.8546 & 0.6182 & 22.70042 & 0.00001 & Accepted \\
\hline & Within & 36 & 0.9804 & 0.0272 & & & \\
\hline & Total: & 39 & 2.8349 & & & & \\
\hline \multirow{3}{*}{$\begin{array}{l}\text { Sources of } \\
\text { Capital }\end{array}$} & Between & 4 & 0.8688 & 0.2172 & 22.26424 & 0.00001 & Accepted \\
\hline & Within & 45 & 0.4390 & 0.0098 & & & \\
\hline & Total: & 49 & 1.3078 & & & & \\
\hline \multirow{3}{*}{$\begin{array}{l}\text { Years in } \\
\text { Operation }\end{array}$} & Between & 3 & 3.0450 & 1.0150 & 40.1089 & 0.00001 & Accepted \\
\hline & Within & 36 & 0.9110 & 0.0253 & & & \\
\hline & Total: & 39 & 3.9560 & & & & \\
\hline \multirow{3}{*}{$\begin{array}{l}\text { Nature of } \\
\text { Business }\end{array}$} & Between & 3 & 0.2111 & 0.0704 & 12.91779 & 0.00001 & Accepted \\
\hline & Within & 36 & 0.1961 & 0.0054 & & & \\
\hline & Total: & 39 & 0.4072 & & & & \\
\hline
\end{tabular}

This implied that developments in entrepreneurial businesses as a distinct area of both research and practice raised about the personal competencies and knowledge of services of entrepreneurial leaders that enable them to successfully lead entrepreneurial endeavors. In spite of the fact that distinguishing business people's particular abilities has been one of the primary focal points of enterprise researchers, our insight is restricted about close to home authority capabilities and learning are required in pioneering settings (Bagheri, Lope Pihie, and Krauss, 2013). Moreover, Educational Background ( $\mathrm{P}$-value $=0.181368$ ) is not significant since the $\mathrm{p}$-value is above 0.05 level of significance. This implied that the respondents have the same level of educational background in the entrepreneurial businesses.

In Table 4 below, the One Way Analysis of Variance on the Entrepreneurial Challenges and Interventions presented to the Respondents in terms of Availment of services when respondents are grouped according to Sex, Marital Status, Educational Background, Business Knowledge, Sources of Capital, Years in Operation and Nature of Business, the data revealed that Sex (P-value=0.000698), Marital Status (P-value=0.000244), 
Educational Background (P-value=0.007473), Business Knowledge (P-value=0.008428), Sources of Capital (Pvalue $=0.00001)$, Years in Operation $(\mathrm{P}$-value $=0.00001)$ and Nature of Business $(\mathrm{P}$-value $=0.000715)$ are below the significant level of 0.05 .

This means that they have significant difference on the entrepreneurial challenges and interventions in terms of availment of services. This implies that the availment of services in the business industry measured by the capability to grow, and the relative importance of each of these sources.

Table 4. Test of Difference of the Respondents' Profile, and Challenges and Interventions in terms of Knowledge of Services

\begin{tabular}{|c|c|c|c|c|c|c|c|}
\hline INDICATORS & Variation & Df & $\begin{array}{l}\text { Sum of } \\
\text { Squares }\end{array}$ & $\begin{array}{l}\text { Mean } \\
\text { Square }\end{array}$ & F-Stat & P-Value & Decision \\
\hline \multirow{3}{*}{ Sex } & Between & 1 & 0.2163 & 0.2163 & 16.67135 & 0.000698 & Accepted \\
\hline & Within & 18 & 0.2336 & 0.013 & & & \\
\hline & Total: & 19 & 0.4499 & & & & \\
\hline \multirow{3}{*}{ Marital Status } & Between & 3 & 0.3894 & 0.1298 & 8.33514 & 0.000244 & Accepted \\
\hline & Within & 36 & 0.5606 & 0.0156 & & & \\
\hline & Total: & 39 & 0.9500 & & & & \\
\hline \multirow{3}{*}{$\begin{array}{l}\text { Educational } \\
\text { Background }\end{array}$} & Between & 2 & 0.2706 & 0.1353 & 5.90224 & 0.007473 & Accepted \\
\hline & Within & 27 & 0.6190 & 0.0229 & & & \\
\hline & Total: & 29 & 0.8896 & & & & \\
\hline \multirow{3}{*}{$\begin{array}{l}\text { Business } \\
\text { Knowledge }\end{array}$} & Between & 3 & 0.5257 & 0.1752 & 4.54399 & 0.008428 & Accepted \\
\hline & Within & 36 & 1.3882 & 0.0386 & & & \\
\hline & Total: & 39 & 1.9139 & & & & \\
\hline \multirow{3}{*}{$\begin{array}{l}\text { Sources of } \\
\text { Capital }\end{array}$} & Between & 4 & 1.9660 & 0.4915 & 17.46193 & 0.00001 & Accepted \\
\hline & Within & 45 & 1.2666 & 0.0281 & & & \\
\hline & Total: & 49 & 3.2326 & & & & \\
\hline \multirow{3}{*}{$\begin{array}{l}\text { Years in } \\
\text { Operation }\end{array}$} & Between & 3 & 2.7521 & 0.9174 & 21.47426 & 0.00001 & Accepted \\
\hline & Within & 36 & 1.5379 & 0.0427 & & & \\
\hline & Total: & 39 & 4.2900 & & & & \\
\hline \multirow{3}{*}{$\begin{array}{l}\text { Nature of } \\
\text { Business }\end{array}$} & Between & 3 & 0.3762 & 0.1254 & 7.11246 & 0.000715 & Accepted \\
\hline & Within & & 0.6347 & 36 & 0.0176 & & \\
\hline & Total: & 39 & 1.0109 & & & & \\
\hline
\end{tabular}

In Problem 7, where the study looked at the significant relationship between entrepreneurial skills, and challenges and intervention in terms of, Business needs, Knowledge of services and Availment of services, the results showed that business needs is not correlated and has no significant relationship to all variables of entrepreneurial skills. Knowledge of services is positively correlated and has significant relationship towards planning and research ( $\mathrm{r}=262 *$, Sig.=.011), Marketing and selling ( $\mathrm{r}=.268^{* *}$, Sig.=.009) and business management $(r=.261 *$, Sig.=.012). 
Table 5. Pearson R Values on the Significant Relationship between Entrepreneurial Skills, and Challenges and Intervention

\begin{tabular}{|c|c|c|c|c|c|c|c|c|c|c|}
\hline \multirow{3}{*}{$\begin{array}{l}\text { Challenges and } \\
\text { intervention }\end{array}$} & \multicolumn{10}{|c|}{ Entrepreneurial skills } \\
\hline & \multicolumn{2}{|c|}{$\begin{array}{l}\text { Creative } \\
\text { Thinking }\end{array}$} & \multicolumn{2}{|c|}{$\begin{array}{l}\text { Planning and } \\
\text { Research }\end{array}$} & \multicolumn{2}{|c|}{$\begin{array}{l}\text { Organization } \\
\text { and Decision } \\
\text { Making }\end{array}$} & \multicolumn{2}{|c|}{$\begin{array}{l}\text { Marketing and } \\
\text { Selling }\end{array}$} & \multicolumn{2}{|c|}{$\begin{array}{l}\text { Business } \\
\text { Management }\end{array}$} \\
\hline & $\mathrm{r}$ & Sig. & $\mathrm{r}$ & Sig. & $\mathrm{r}$ & Sig. & $\mathrm{r}$ & Sig. & $\mathrm{r}$ & Sig. \\
\hline Business needs & .063 & .546 & .092 & .380 & .068 & .517 & .014 & .895 & .060 & .568 \\
\hline $\begin{array}{l}\text { Knowledge of } \\
\text { services }\end{array}$ & .140 & .182 & $.262 *$ & .011 & .190 & .068 & $\begin{array}{l}.268 * \\
*\end{array}$ & .009 & $.261 *$ & .012 \\
\hline $\begin{array}{l}\text { Availment of } \\
\text { services }\end{array}$ & $.221^{*}$ & .033 & $.208 *$ & .045 & $.207^{*}$ & .047 & $.258^{*}$ & .013 & $\begin{array}{l}.346^{*} \\
*\end{array}$ & .001 \\
\hline
\end{tabular}

*. Correlation is significant at the 0.05 level (2-tailed).

**. Correlation is significant at the 0.01 level (2-tailed).

If the respondents will increase the knowledge of the services, then there will be an increase and development towards planning research, marketing and selling and business management. This will also leads to organizational outcomes resulting from entrepreneurial actions, including the development of competitive capability and strategic repositioning (Ireland, Covin, \& Kuratko, 2009). Moreover, availment of services is correlated and has significant relationship to creative thinking $\left(\mathrm{r}=.221^{*}\right.$, Sig.=.033), planning and research ( $\mathrm{r}=.208^{*}$, Sig.=.045), organization and decision making ( $\mathrm{r}=.207^{*}$, Sig.=.047), marketing selling ( $\mathrm{r}=.258^{*}$, Sig.=.013) and business management $\left(r=.346^{* *}, \mathrm{Sig} .=.001\right)$. Thus, a constant increase on availment services the all the variables of entrepreneurial skills develop. It also denotes entrepreneurship promotion and economic development, such as education and institutional deregulation as application (Akçomak, 2011).

In Problem 8, the study looked at the significant relationship between entrepreneurial skills, and success rate in business in terms of increase in number of employees, income and production. The data shows that increase in number of employees has no significant relationship towards all variables in entrepreneurial skills. Increase in income is correlated and has significant relationship to planning and research $(r=.222 *$, Sig. $=032)$.

Table 6. Pearson R Values on the Significant Relationship Between Entrepreneurial Skills and Success in Business

\begin{tabular}{|l|l|l|l|l|l|l|l|l|l|l|}
\hline \multicolumn{8}{|l|}{ Entrepreneurial Skills } \\
\hline $\begin{array}{l}\text { Success in } \\
\text { Business }\end{array}$ & $\begin{array}{l}\text { Creative } \\
\text { Thinking }\end{array}$ & $\mathrm{r}$ & \multicolumn{2}{l|}{$\begin{array}{l}\text { Planning and } \\
\text { Research }\end{array}$} & $\begin{array}{l}\text { Organization } \\
\text { and Decision } \\
\text { Making }\end{array}$ & $\begin{array}{l}\text { Marketing } \\
\text { and Selling }\end{array}$ & \multicolumn{2}{l}{$\begin{array}{l}\text { Business } \\
\text { Management }\end{array}$} \\
\cline { 2 - 12 } & $\mathrm{r}$ & Sig. & $\mathrm{r}$ & Sig. & $\mathrm{r}$ & Sig. & $\mathrm{r}$ & Sig. & $\mathrm{r}$ & Sig. \\
\hline $\begin{array}{l}\text { Increase in no. } \\
\text { employees }\end{array}$ & .171 & .101 & .038 & .720 & .034 & .743 & .049 & .643 & .099 & .346 \\
\hline $\begin{array}{l}\text { Increase in } \\
\text { income }\end{array}$ & .047 & .654 & $.222 *$ & .032 & .157 & .132 & .023 & .830 & .003 & .981 \\
\hline $\begin{array}{l}\text { Increase in } \\
\text { production }\end{array}$ & .078 & .458 & $.209 *$ & .044 & $.239 *$ & .021 & .088 & .403 & .043 & .681 \\
\hline
\end{tabular}

*. Correlation is significant at the 0.05 level (2-tailed).

**. Correlation is significant at the 0.01 level (2-tailed). 
The table also shows that increase in production is correlated and has significant relationship to planning and research $\left(\mathrm{r}=.209^{*}\right.$, Sig.=.044) and organization and decision making $\left(\mathrm{r}=.239^{*}\right.$, Sig.=.021). This implies the relevance of good planning and research as it impacts productivity and income. Several literatures show that increases in production is possible through good research as this supports good decision making skills for the entrepreneurs (Shepherd, 2011).

In every growing business, the need to make succinct, clear and data driven decisions become more critical. Decisiveness is management skill and this can be augmented through deep, proper, appropriate and innovative business research. Organizations are a systemic network that is both dynamic and complex, planning and research are the primary skills needed to arrive at good decision making.

In this study, it has be shown that skills in planning, research and decision making are positively correlated to increases in income and production. Especially in the advent of technology and growing number of business disruptors (e.g. Airbnb for hotels, Grab and Uber for transportation, Lazada for online shopping, etc), that has happened over the past decade, market and business research must be areas that every business have to fully focus into even for new and emerging local business. In Honig et. al (2014), it was found that planning is especially crucial for start-up businesses. The higher the quality of planning, the greater is the chance for business success. Also, when looking at Table 6, under the indicator of planning and research, the respondents recognized their need to develop planning skills especially in researching business information and utilizing it.

In Problem 9, where the study looked at creating a capability building program to improve the success rate of businesses among MSEs. The study was helpful in identifying the key determinants of success among clients of a Trade and Industry Government Agency. Of the several entrepreneurial skills looked into as determinants for business success, it was found that planning and research, and organizational decision making are most crucial. They have been found to be directly correlated to increases in income and production.

The existing program of the Negosyo Center does cater to the improvement of entrepreneurial skills and through this research, it is recommended to put more focus into these two competencies discovered to be relevant for business success. The Center has an existing Enterprise Development Track (EDT) where the recommended action plan can be customized as focus areas. This Enterprise Development Track is a tier based, graded intervention that will complement their existing business knowledge, skills and competencies sustain and improve business success. The action plan of this EDT should focus on strengthening the entrepreneurs planning, research and decision making skills. In consultation with the DTI Provincial Negosyo Center Coordinator, it is then recommended to enhance, augment and improve the planned implementation of the Enterprise Development Track (EDT) to include the significant variables as the results of this study.

The Enterprise Development Track (EDT) is a support of the initiatives under the MSMED Plan 2017-2022, Philippine Development Plan 2017-2022, Philippine ASEAN Economic Community 2025 Game Plan and Ambisyon Natin 2040 which intend to pursue the strengthening and promotion of MSMEs both in domestic and cross border context. The EDT is a framework for mapping the current level of MSEs in the development path with corresponding interventions to facilitate MSEs further progress. Enterprise Development Track (EDT) objectives are to guide enablers in providing the required interventions at any level of an enterprise development and to monitor and steer the course of MSEs in the development track towards the level of sustainability.

\section{Conclusion}

Results of the study showed the need for an enhanced and improved Capability Building Program called Enterprise Development Track (EDT) is needed to strengthen and sustain the MSEs. Going over the services of the Negosyo Center, it is determined that the center excellently provided services to MSEs despite the lean human capital, considering the numerous activities of the center. This is also takes into consideration that the center was able to achieve $98 \%$ client satisfaction rating of its services. All of the participant business also 
reported a positive success rating where all MSEs attributed this to Negosyo Center interventions. This recommended enhancement should focus on planning and research and organizational decision making.

Also one of significant responses from MSEs is to expand its reach and do extensive promotion of services. Admittedly the Negosyo Center could not provide developmental interventions to all MSEs. That is why a screening process and setting of effective criteria is important in delivering services to MSMEs.

It is important to notice that MSEs recognizes access to finance as one of the crucial needs in doing business, and at the same time, many of them suggested that financial assistance should be added as a necessary service of the Negosyo Center. However its service of facilitating access is only ranked 8th as most utilized service and only ranked 10th as most significant service. This is either because the respondents would rather prefer grants or non-collateralized financing window for start-ups. It is also good to know that client MSEs mostly acquired their knowledge and skills in business through trainings and work experience. This means that anyone can go into business even without the degree. This makes intervention of the Negosyo Center all the more critical for the success of MSEs as these businesses will need the guidance and input of the Negosyo Center.

Furthermore, the study also proves that some have a chance to gain knowledge and skills in business as most MSEs stated that they gained knowledge and skills, either by getting trainings or by work experience. This is consistent with the results that the most availed of services of the Negosyo Center are the coaching sessions, trainings and seminars. Market exposure and participation in Trade fairs is the service of the Negosyo Center which is most essential to MSEs and it is also their 5th most availed service. This proves that the opportunity to market products is significant to the MSEs.

\section{References}

Ahmad, H., 2010. Personality Traits among Entrepreneurial and Professional CEOs in SMEs. International Journal of Business and Management, Volume 5, Number 9, p. 203-213.

Akçomak, 2011. "Social Capital of Social Capital Researchers," Review of Economics and Institutions, Università di Perugia, vol. 2(2).

Almeda, S.Z, Baysic-Pobre, I.S., 2013. Micro, small and medium enterprises (MSMEs) in the Philippines: What we know and What we don't know. Asian Institute of Management

Bagheri, A., Z.A. Lope Pihie and S.E. Krauss, 2013. Entrepreneurial leadership competencies among Malaysian university student entrepreneurial leaders. Asia Pacific Journal of Education, 33(4): 493-508

Bulut, Y. et al., (2010). An Evaluation of Entrepreneurship Characteristics of University Students: An Empirical Investigation from the Faculty of Economic and Administrative Sciences in Adnan Menderes University. International Journal of Economic Perspectives, Volume 4, Issue 3, p. 559-568

Cantillon, R., (1755), Essay on the nature of commerce in general, Fondo de Cultura Económica, Mexico, 1978, 235 pages.

Carland Jr., J. and Carland, J., (1997). Entrepreneurship: An American Dream. Journal of Business and Entrepreneurship, Volume 9, Number 1, ABI/INFORM, p. 33-45

Chen, C.C., Greene, P.G., \& Crick, A. (1998). Does Entrepreneurial Self-efficacy Distinguish Entrepreneurs from Managers? Journal of Business Venturing, 13(4), 295-316.

Davidsson, P., Delmar,F. \& Wiklund, J. (2006) - Entrepreneurship as Growth: Growth as Entrepreneurship - In Davidsson, P, Delmar, F, \& Wiklund, J (Eds.) 'Entrepreneurship and the Growth of Firms', Edward Elgar Publishing, United Kingdom, England, Cheltenham, pp. 21-38

Dollinger, M., (1995). Entrepreneurship: Strategies and Resources. Illinois: Irwin.

Estrin and Mickiewicz, (2011). Institutions and female entrepreneurship. Small Business Economics.

Gulbro, R. D., Shonesy, L., \& Dreyfus, P. (2004). Are small manufacturers failing the quality test? Industrial Management \& Data Systems, 100(2), pp. 76-80. 
Hampel-Milagrosa A., 2014. Micro and Small Enterprise Upgrading in the Philippines: The role of the entrepreneur and enterprise

Hampel-Milagrosa, A. / M. Loewe / C. Reeg (2013): Which factors determine the upgrading of micro, small and medium-sized enterprises? Evidence from Egypt, India and the Philippines

Hanush, H. and Pyka, A., (2007). Elgar Companion to Neo-Schumpeterian Economics, Edward Elgar, Cheltenham, p. 857

Harvie, C., \& Lee, B. C. (Eds.). (2002). The role of SMEs in national economies in East Asia (Vol. 2). Edward Elgar Publishing.

Hayward, Mathew and Shepherd, Dean and Griffin, Dale W., A Hubris Theory of Entrepreneurship (2006). Management Science, Vol. 52, Issue 2, p. 160-172

Henry, C., Hill, F. And Leitch, C. (2003) - Entrepreneurship Education and Training - Ashgate, Aldershot

Hisrich, R., et al., (2013). Entrepreneurship, 9th ed. New York: McGraw-Hill

Honig, B., \& Samuelsson, M. (2014). Data replication and extension: A study of business planning and venturelevel performance. Journal of Business Venturing Insights, 1, 18-25.

Ireland, R. D., D. F. Kuratko, and M. H. Morris. 2006b. "A health audit for corporate entrepreneurship: Innovation at all levels_-Part I”. Journal of Business Strategy. 27(1): 10-17.

Jasra, J. M., Hunjra, A. I., Rehman, A. U., Azam, R. I., \& Khan, M. A. (2011). Determinants of business success of small and medium enterprises. International Journal of Business and Social Science.

Kuratko, D. and Welsch, H., 2004. Strategic Entrepreneurial Growth, 2nd ed. Ohio: Thompson South-Western.

Littunen, H., (2000). Entrepreneurship and the characteristics of the entrepreneurial personality. International Journal of Entrepreneurial Behavior \& Research, Volume 6, Issue 6, p. 295-310.

Lussier, R., and J. Corman. (1995). There are few differences between successful and failed small businesses. Journal of Small Business Strategy, 6(1), 21-33.

Markman, G.D., (2007), 'Entrepreneurs' competencies', in J.R. Baum, M. Frese \& R.A. Baron (eds.), The psychology of entrepreneurship, pp. 67-92, Psychology Press, New York.

Mason and Brown, (2013), Small Business Economics, vol. 40, issue 2, 211-225

McClelland, D. C. (1961). The achieving society. Princeton: Van Nostrand.

McGowan C, et. al (2014) "What matters in business incubation? A literature review and a suggestion for situated theorizing", Journal of Small Business and Enterprise Development, Vol. 21 Issue: 4, pp.602-622, https://doi.org/10.1108/JSBED-09-2014-0152

McLarty, R. \& Dousios, D., 2006, 'Dynamics and patterns of skills within small and medium-sized enterprises', Strategic Change 15(4), 175-186. https://doi.org/10.1002/jsc755

Md. Shafiul Alam, Golam Mohiuddin, 2014. Chronological Development of Entrepreneurship Concept - A Critical Evaluation.

Scase, R. (2000), Entrepreneurship and Proprietorship in Transition: Policy Implications for the Small- and Medium-size Enterprise Sector - Helsinki: United Nations University World Institute for Development Economics Research

Schaper, Michael (2004), Entrepreneurship and Philanthropy: The Case of Small Australian Firms, Milton: John Wiley \& Sons Australia, Ltd

Schumpeter, J.A., 1934 (2008), The Theory of Economic Development: An Inquiry into Profits, Capital, Credit, Interest and the Business Cycle, translated from the German by Redvers Opie, New Brunswick (U.S.A) and London (U.K.)

Shane, S., (2003). A General Theory of Entrepreneurship: The Individual-Opportunity Nexus. Cheltenham: Edward Elgar Publishing Ltd. 
Sriram V, et al., (2007) "Drivers of urban entrepreneurship: an integrative model", International Journal of Entrepreneurial Behavior \& Research, Vol. 13 Issue: 4, pp.235-251, https://doi.org/10.1108/13552550710760012

Thomas, A.S. and Mueller, S.L. (2000), "A case for comparative entrepreneurship: assessing the relevance of culture", Journal of International Business Studies, Vol. 31 No. 2, pp. 287-301.

Thomas, A.S. and Mueller, S.L. (2000), "A case for comparative entrepreneurship: assessing the relevance of culture”, Journal of International Business Studies, Vol. 31 No. 2, pp. 287-301.

Westhead, P. et al., (2011). Entrepreneurship: Perspectives and Cases. Essex: Pearson Education Ltd.

Yusuf, A. (1995). Critical success factors for small business: Perceptions of south pacific entrepreneurs. Journal $\begin{array}{llllll}\text { of Small } & \text { Business } & \text { Management, } & 33(2), & \text { Retrieved }\end{array}$ http://search.proquest.com/docview/221005097?accountid=47253

Zhang, D. and Bruning, E., 2011. Personal characteristics and strategic orientation: entrepreneurs in Canadian manufacturing companies. International Journal of Entrepreneurial Behavior \& Research, Volume 17, Issue 1, p. 82-103.

Zimmerer, T. and Scarborough, N., 1996. Entrepreneurship and the New Venture Formation. New Jersey: Prentice Hall. 